OPEN ACCESS

Edited by:

Ana Lucia Pereira, Universidade Estadual de Ponta

Grossa, Brazil

Reviewed by:

Pamela Garner,

George Mason University,

United States

Susanne Ayers Denham George Mason University,

United States

*Correspondence:

Sabina Valente

sabinavalentte@gmail.com

Specialty section:

This article was submitted to

Educational Psychology,

a section of the journal

Frontiers in Education

Received: 23 July 2019

Accepted: 20 January 2020

Published: 25 February 2020

Citation:

Valente $S$ and Lourenço $A A$ (2020) Conflict in the Classroom: How Teachers' Emotional Intelligence Influences Conflict Management. Front. Educ. 5:5

doi: 10.3389/feduc.2020.00005

\section{Conflict in the Classroom: How Teachers' Emotional Intelligence Influences Conflict Management}

\author{
Sabina Valente ${ }^{1 *}$ and Abilio Afonso Lourenço ${ }^{2}$ \\ ${ }^{1}$ Department of Education and Psychology, School of Human and Social Sciences, University of Trás-os-Montes and Alto \\ Douro, Vila Real, Portugal, ${ }^{2}$ Institute of Education, University of Minho, Braga, Portugal
}

Distinct studies showed a positive relationship between emotional intelligence and conflict management. However, there is a lack of research on how teachers' emotional intelligence influences conflict management in the classroom. Since much more needs to be learned about how teachers' emotional skills related to classroom practice, this research has emerged, and the purpose went to examine how teachers' emotional intelligence influences classroom conflict management. Moreover, the relationship between gender, teaching experience, and academic training with teachers' emotional intelligence was also analyzed. The sample comprised of 382 Portuguese teachers. The Emotional Skills and Competence Questionnaire for Teachers, the Rahim Organizational Conflict Inventory II-Portuguese Version in School Context, and a personal and professional data inquiry were been used as instruments. Structural equation modeling showed that teachers who tend to have higher levels of emotional intelligence employ more integrating and compromising strategies for conflict management, therefore constructively managing conflict in the classroom. In light of these findings, emotional skill programs should be included in teachers' academic training to promote their emotional intelligence and give them tools to constructively manage classroom conflict.

Keywords: emotional intelligence, conflict management strategies, teacher-student, classroom, school

\section{INTRODUCTION}

In recent years, conflict situations are a frequent reality in Portuguese schools, and their identification, understanding, and management characterize a continuous concern area for the psychologists and education science professionals, fundamentally because of their impact on the teachers' performance. These conflicts affect the quality of the learning environment and the teachers' performance. In this sense, emotions affect the teacher-student relationship and help to understand the classroom climate profile (Meyer and Turner, 2007), so when positive emotions are developed, it is more likely that conflicts are successfully solved (Jordan and Troth, 2004). Therefore, emotional intelligence (EI) is an emerging topic of education research since emotional relationships between teachers and students are the more important part of the teaching and learning process. 
Frequently identified causes of conflict include lack of EI, personality traits, various aspects of the work environment, role ambiguity, poor communication, and lack of support from colleagues or management (Almost et al., 2016). Also, Leung (2010) argued that a high emotional quotient is related to high problem-solving success. They stated that EI is an essential variable for conflict management, as it encourages the negotiator to worry about the opponent's interests. Considering that negative emotions are related to conflict experiences in the workplace, Rispens and Demerouti (2016) indicated that it is essential to investigate the relationship between EI and school conflict. In this sense, the relevance of present research, and considering the lack of studies that report the relationship between teachers' EI and classroom conflict management, is to contribute with empirical evidence, helping to overcome the existing gap on the investigation of these two constructs, in the teacher-student relationship.

The researches, in Portugal, about teachers' EI, is still few, and considering the literature that indicated the lack of research linking teachers' EI and classroom conflict management (Hopkins and Yonker, 2015; Rispens and Demerouti, 2016), arose this research from the need to discuss the importance of teachers' EI for classroom conflict management. In that way, this research focused on the influence of teachers' EI as a factor that affects conflict management. In this sequence, the following question arose: "How does teachers' EI influence classroom conflict management?" So the purpose of this research is to investigate the relationship between teachers' EI and the different strategies of managing conflict, applied to manage conflict in the teacherstudent relationship in the classroom. This is an important focal area given the pervasiveness of classroom conflict, in Portuguese schools. How gender, teaching experience, and academic training relate to teachers' EI will also be studied.

\section{Emotional Intelligence in the Classroom}

Mayer and Salovey (1997) defined EI as a set of capabilities, involving the capacity to correctly perceive, evaluate, and express emotions, generate feelings to facilitate thinking; understand emotion and emotional knowledge, and regulate emotions to promote personal and intellectual growth. These four capacities constitute the levels of the Four Branch Model that point to a hierarchy, a growing complexity of emotional skills, according to the degree of integration from EI, from the first level to the fourth level, from perception to emotional management (Mayer and Salovey, 1997). That is, EI fits into a developmental process, starting with perception as the most basic psychological process and ending with effective emotional regulation as the most advanced and complex process (Mayer et al., 2016). The integration of emotional components with the cognitive component is evident, according to great importance to feelings and emotions in the rationalization of behaviors, being considered by many researchers as the most acceptable and appropriate theoretical model of EI (Tarasuik et al., 2009).

In almost three decades of EI's scientific existence, it has proved to be a productive field of research in different areas, especially in the educational area (Cejudo and López-Delgado, 2017). In the classroom, teachers are the main emotional leaders of the students, and the capacity to perceive, understand, and regulate the emotions is the best indicator of the emotional balance of the class (Fernández-Berrocal and Extremera, 2002). In that way, teachers who can perceive and express emotions can identify the emotions and their contents. As an example, when teachers perceive discouragement in students' faces, after decoding information about facial expressions, they change the pace of the lesson, giving an example to make the explanation most understandable of the theme.

The second capacity, emotional facilitation of thinking, refers to the use of emotion to aid thinking and action (Mayer et al., 2002). Teachers, by inducing an emotional state in their students, increase creative and innovative thinking, for example, by introducing music in the classroom to create a favorable emotional state in the development of creative activities, such as writing poetry or performing artistic activities (Fernández-Berrocal and Extremera, 2005). In its turn, emotional understanding involves cognitive processing of emotion (Mayer and Salovey, 1997), referring to the capacity for distinguishing emotions, as well as understanding complex feelings. The teacher must develop empathic behavior with the students to perceive, recognize, and become aware of the students' feelings and express this understanding to them. This provides a closer connection to the relationship of affection necessary for the quality of teaching and learning. Developing these empathic skills in students also means teaching them that we do not all feel the same in similar situations and toward the same people, that individuality guides our lives, and that each person experiences different needs, fears, desires, and hates (Fernández-Berrocal and Extremera, 2002).

As for the last capacity, it refers to the highest level of the hierarchy of EI capacities and represents the capacity to moderate or manage one's emotional reactions toward intense situations, whether positive or negative. Emotional regulation involves the capacity to be open to, and reflect upon, feelings, both positive and negative, by excluding or taking advantage of the information that accompanies them according to their usefulness. It includes the capacity to control and regulate emotions of one's own and those of others, moderating negative emotions and increasing positive ones (Mayer and Salovey, 1997). Teaching is considered one of the most emotionally distressing works, thus the application of emotional regulation is essential and recommended for all who want to avoid anxiety or depression (Fernández-Berrocal and Extremera, 2005). Therefore, the development of teachers' capacity for emotional regulation increasingly represents a crucial component for the improvement of their interpersonal and professional relationships.

Emotional processes are evident in the classroom, where interpersonal relationships can generate a beneficial development, as well as the wear and suffering of the teacher and students, undermining the teaching and learning process. The role of teachers' EI is of great significance, for it contains a lot of verbal and non-verbal competencies that empower the teacher to articulate, identify, understand, and evaluate his own and students' feelings. Thus, the EI contributes to monitoring teacher feelings and correctly deals with students' emotions (Goleman et al., 2002). Teaching is an emotional activity, and the teachers' work contains a significant emotional 
workload, wherein both requires sensitivity and understanding about how to manage and regulate emotions, to facilitate and optimize the quality of interpersonal relationships, as well as to manage the conflicts that arise in the teacher-student relationship. Therefore, the teachers' activity encourages the implementation of strategies for perception, understanding, and management of emotions, since discipline, confrontation with students, and successive loss of authority have led teachers to the limit of their resistance (Brackett et al., 2010), particularly, when it is verified that Portugal is one of the countries in Europe where teachers are more stressed, and a large number are at risk of developing burnout (Correia and Veiga-Branco, 2012). Nowadays, teachers are subject to violent emotional wear and tear, which not only affects their own (e.g., reduced psychological well-being, weakened social relations), such as school organization (e.g., absenteeism), but also the students (Extremera and Fernández-Berrocal, 2004). In this sense, the bibliography review of Carvalho (2017) reports that 45 to $63 \%$ of Portuguese teachers evaluated their professional activity as very or extremely stress generating. It should be noted that researches indicated that individuals with high EI are more confident, creative, flexible, have a greater capacity to deal with stress and with their own emotions, being, therefore, the ones that present greater problem solving (Hein, 1996) and better performance at work (Shih and Susanto, 2010).

Researches also showed the effectiveness of positive action in the development of teachers' emotional skills, increasingly recognizing teachers being emotionally intelligent as the basis for a good relationship with students, for providing a steady and wholesome classroom environment (Maamari and Majdalani, 2019). Other researches confirmed that school teachers' EI is a stress and burnout protection factor (Brackett et al., 2010; Schoeps et al., 2019), associated to higher professional performance, lower feelings of tiredness (Extremera et al., 2016), helpful for the teaching-learning process (Chan, 2006), related to promotion of an appropriate emotional climate (Jennings and Greenberg, 2009), and also to an effective classroom management (Valente, 2019). Highlighting that despite several studies that related teachers' EI to other variables, Rispens and Demerouti (2016) indicate the significance of the relationship between schoolteachers' EI and classroom conflict management, emphasizing the lack of this kind of study. Moreover, studies of neuroscience indicated that the essential element for learning is emotion since without emotion there is no curiosity, no attention, no learning, and no memorization (Mora, 2013). In this sequence, the presence of emotionally intelligent teachers in the classroom is essential, as the different traits of teachers' EI are the dynamic factor for successful schooling.

Variables such as gender, teaching experience, and academic training impact teachers' EI, and studies have shown that women generally score higher on EI measures than men (Gill and Sankulkar, 2017; Valente, 2019). Also, teachers with more advanced degrees (e.g., Ph.D.) tend to have higher EI levels (Sousa, 2011; Fernandes, 2015; Valente, 2019). Research has also shown that length of teaching experience tends to correlate negatively with schoolteacher EI (Sousa, 2011; Valente, 2019), so teachers who have fewer years of teaching experience reveal a higher EI, contrary to their colleagues with more teaching experience.

\section{Conflict on the Teacher-Student Relationship}

Inherent in the human condition, conflict with the other, with one's own, and with the institution, is at the heart of the educational relationship (Pérez-de-Guzmán et al., 2011), whose causes are due to differences in culture, personality, values, needs, interests, and power (Almost et al., 2016). Thus, it is impossible to think of a school where there are no conflict situations, so the existence of conflict is part of everyday life, revealing itself in the mirror of social conflict and, thus a place conducive to the occurrence of conflicts.

School conflict is defined as the disagreement between individuals or groups regarding ideas, interests, principles, and values within the school community, perceiving the parties their interests as excluded, although they may not be (Pérez-Serrano and Pérez-de-Guzmán, 2011). As stated by Silva and Dota (2013) "Conflict episodes are part of the everyday life of any school, which makes teachers need to work with conflict rather than against it" (p. 69). In the absence of necessary skills, teachers who are unable to solve and manage conflict situations are confronted with one of the most important time-wasting problems that must be applied in students' education and instruction (Argon, 2014).

The most frequent school conflicts occur between studentsstudents and students-teachers (Hojbotãa et al., 2014). In that way, Shahmohammadi (2014) indicated the conflicting attitudes of students that include a wide range of unacceptable behaviors such as lack of classroom participation, causing and disrupting peers and situations of violence (e.g., verbal: offending peers; and physical: destroying school facilities and equipment, as well as peer materials). For conflicts in the teacher-student relationship, Göksoy and Argon (2016) indicated the following causes: (a) failure in communication (e.g., indifference, disrespect, personal judgment, persistence, misunderstanding); (b) personal origin (e.g., unnecessary complaints, high expectations/ambitions, prejudices, and cultural-economic differences); (c) political/ideological (e.g., contempt for different ideas, intolerance, and insistence on personal judgments); and (d) organizational causes (e.g., failure to follow rules, neglect of duty, negative impact of social environment, curriculum, failure to educate, and unfair practices in the distribution of tasks).

Conflict outcomes affect individuals, and how interpersonal conflict management takes place determines whether outcomes are positive or negative (Park and Antonioni, 2007). Therefore, Morris-Rothschild and Brassard (2006) indicated that constructive strategies for conflict management are important in maintaining a positive classroom environment, but little is known about the interpersonal or school variables related to teachers' use of these strategies with students. Other authors also confirmed the lack of this type of research in the educational environment (Hopkins and Yonker, 2015; Rispens and Demerouti, 2016).

The conflict management presents many strategies and different practices. Conflict management strategies are the types 
of behavior that are adopted in a conflict context. These are basic strategies in managing a situation where the parties regard their interests as incompatible. For Rahim (2002), a strategy is considered appropriate if its use leads to the effective resolution of a conflict. Based on the perspective of Rahim and Bonoma (1979), the strategies used by the parties to deal with the conflict are classified in terms of how two variables intersect: (a) desire to satisfy the interests of the counterparty (concern for others, the individual tries to satisfy the interests of others and preserve a positive relationship with them) and (b) desire to satisfy one's own interests, showing concern for oneself, seeking to achieve one's personal goals. The different articulations of these two dimensions, self-interest, and interest of the other, gave rise to five strategies for conflict management: integrating, dominating, obliging, avoiding, and compromising.

Integrating is a conflict management strategy also called for collaboration, cooperation, or problem solving, where there is a concern to satisfy one's own interests and those of the others. According to Rahim (2002), individuals who use this strategy manage conflicts directly and cooperatively, seeking to solve in collaboration with the other. It is important to state that it is a strategy that expresses a conduct orientation characterized by high cooperation and high assertiveness (Medina and Munduate, 2005). This strategy requires openness, information exchange, and analysis of differences between the parties, to reach a solution that satisfies those involved in the conflict (Rahim, 2002). Dominating strategy is characterized by a high concern for own interests and low concern for the others, reflecting the attempt to satisfy one's own interests without consideration of the interests of the other (Rahim, 2002). By using this strategy, the teacher seeks to achieve his goals by sacrificing the students', feeling that conflict can be controlled by mastering and suppressing the student's needs and expectations. This is characterized by a high assertiveness and lack of cooperation, in which the acquisition of objectives is viewed with supremacy over the interests of the other party (Medina and Munduate, 2005). The obliging strategy represents the willingness to satisfy the benefits of the others while neglecting one's own interests (Rahim, 2002), that is, when the teacher, in the presence of classroom conflict, values the interests of the students over his/her interests. When this strategy is adopted, the teacher faces the conflict passively and complacently, following the students' decisions. It is a conflict management strategy in which cooperation is high and assertiveness is low (Medina and Munduate, 2005). In avoiding strategy, the individual ignores or neglects the interests of both parties, avoids getting involved in the conflict, and allows occurrences to follow their course without attempting to conflate to the satisfaction of the interests of either party (Rahim, 2002). In the classroom, by using this strategy, the teacher demonstrates low concern for the students' own goals and objectives, staying out of the situation that causes the conflict, or remains neutral in the classroom. This strategy is characterized by a low degree of assertiveness and a low degree of cooperation, where neither its interests nor those of its opponents are satisfied (Medina and Munduate, 2005). Compromising strategy represents the attempt to satisfy, moderately and partially, the interests of all those involved in the conflict (Rahim, 2002).
According to the literature review, only one study was found that related teachers' $\mathrm{EI}$ and classroom management conflict (Aliasgari and Farzadnia, 2012), with 102 high school teachers. The authors indicated a positive and significant relation between EI and a conflict management strategy, which means that the teachers' EI affects their quality of dissolving disagreements and conflict management strategies. They concluded that teachers prefer the strategy of integrating into other strategies to resolve conflicts. In other work contexts, several studies revealed that EI amplifies individual trends for the selection of specific conflict management strategies (Rahim and Psenicka, 2002; Heris and Heris, 2011). So, Henderson (2006), in a study with 229 university students, found a positive correlation between EI and the use of the integrating strategy. Of the five conflict management strategies, EI presented the most significant positive relationship with the integrating strategy, generally considered to be the best approach in dealing with conflicts. Research results from Heris and Heris (2011) confirmed a positive relationship between EI and integrating and compromising strategies, and negative relationship with dominating and avoidance strategies, finding no relationship with the obliging strategy. In the same way, Shih and Susanto (2010), in a study of 300 civil servants, found that EI predicts integrating and compromising strategies. Morrinson (2008), in a study with nurses, confirmed a positive relationship between EI and integration strategy and found a negative relationship with obliging, avoiding, and dominating strategies, coincident with other studies (Jordan and Troth, 2004; Godse and Thingujam, 2010). Also, Villamediana et al. (2015) showed a negative correlation between EI and obliging and dominating strategies.

Based on this literature, the following hypotheses were formed: Hypothesis (1) A positive and statistically significant relationship is predicted between gender and teachers' EI; Hypothesis (2) A positive and statistically significant relationship is predicted between academic training and teachers' EI; Hypothesis (3) A negative and statistically significant relationship is predicted between teaching experience and teachers' EI; Hypothesis (4) A positive and statistically significant relationship is expected between teachers' EI and integrating strategy; Hypothesis (5) A positive and statistically significant relationship is expected between teachers' EI and compromising strategy; Hypothesis (6) A negative and statistically significant relationship is expected between teachers' EI and obliging strategy; Hypothesis (7) A negative and statistically significant relationship is expected between teachers' EI and dominating strategy, and Hypothesis (8) A negative and statistically significant relationship is expected between teachers' EI and avoiding strategy.

\section{MATERIALS AND METHODS}

\section{Sample}

A convenience sample was collected, consisting of 382 teachers (7th to 12 th grades); $33.0 \%$ were men and $67.0 \%$ women, from public schools located in northern Portugal. Of these, $3.7 \%$ have a bachelor's degree, $70.4 \%$ have a post-graduate degree, $23.6 \%$ have a master's degree, and $2.4 \%$ have a Ph.D. Regarding teaching 
experience, $7.6 \%$ have less than 10 years, $26.4 \%$ between 10 and 20 years, $40.6 \%$ between 21 and 30 years, and $25.4 \%$ have more than 30 years of teaching experience.

\section{Instruments}

\section{Personal and Professional Data Inquiry}

A personal and professional data inquiry was used to collect information about teachers' gender, teaching experience, and academic training.

\section{Teacher Emotional Intelligence}

Emotional intelligence was measured with the Emotional Skills and Competence Questionnaire for Teachers (ESCQ-T; Valente and Lourenço, peer review), adapted, and validated from the Emotional Skills and Competence Questionnaire (ESCQ; Takšić, 2001). ESCQ-T includes 45 items distributed among three subscales: (a) Perceive and understand emotions, 15 items (e.g., When I see how a student feels, I usually know what has happened to him); (b) Express and classify emotions, 14 items (e.g., I can express my emotions well); and (c) Manage and regulate emotions, 16 items (e.g., I can stay in a good mood even if something unpleasant happens in the classroom). Participants answered on a six-point Likert scale ( $1=$ never; $6=$ always $)$. The internal stability in this sample was satisfactorily adequate with Cronbach's $\alpha=0.90$.

\section{Conflict Management Strategies}

Conflict management strategies were measured with the Rahim Organizational Conflict Inventory-II-Portuguese Version in School Context (ROCI-II-PViSC; Valente et al., 2017), resulting from the adaptation and validation of Rahim Organizational Conflict Inventory-II, form B (ROCI-II; Rahim, 1983). ROCIII-PViSC includes 28 items distributed among five subscales: (a) Integrating, seven items (e.g., In a difficulty working with a student, I try to analyze the situation with him to find a solution acceptable to both); (b) Obliging, six items (e.g., Faced with a work problem, I usually try to meet the needs of my student); (c) Dominating, five items (e.g., In a problematic situation with a student, I usually stand firm to seek to impose my point of view); (d) Avoiding, six items (e.g., I try not to disagree with students); and (d) Compromising, four items (e.g., In facing work problems, I try to reach agreements with my students). Teachers' responses were evaluated on a five-point Likert scale $(1=$ totally disagree; 5 = totally agree). The internal stability in this sample was adequate with Cronbach's $\alpha=0.80$.

\section{Procedures}

Researchers administered the instruments, in groups of 20-25 teachers, in the school, during a session lasting from $30 \mathrm{~min}$. Teachers were informed about the research objective. The conventional ethical and deontological procedures were followed, especially regarding data confidentiality and participants' written consent to participate. Of all the 450 surveys, $84.8 \%$ of the teachers agreed to participate with the research, and only $15.2 \%$ were not filled in due to a lack of teacher availability. No missing data were recorded, all participants completed the questionnaires, and all the data were considered valid. Evaluation instruments were applied in 2017-2018. All the research procedures received approval from the General Directorate of Education from the Ministry of Education (Registration $n^{\circ}$ 0512400001/MIME), researchers' institution's ethics committee, school directors, and teachers' participants.

\section{Data Analysis}

The data were analyzed using SPSS/AMOS 25 (Arbuckle, 2012). Descriptive statistics, Pearson's correlation tests, and the structural equation models (SEM) (Lowe et al., 2007) were used. The Hoelter index (Hoelter, 1983) indicates the sufficiency of a sample size to be able to properly adjust the model and must be equal to, or greater than, 200 to indicate that the model closely represents the sample data. Pearson's $r$ correlation tested the relationships between model variables. For the descriptive data corresponding to variables included in SEM, the criteria used eliminated from consideration any asymmetry values greater than two or kurtosis scores higher than seven (Finney and DiStefano, 2013). For Pearson's coefficient $r$, it is assumed that (a) an $r<0.200$ indicates very low; (b) between 0.200 and 0.399 , low; (c) between 0.400 and 0.699 , moderate; (d) between 0.700 and 0.899 , high; and (e) between 0.900 and 1, very high (Pestana and Gageiro, 2014).

\section{RESULTS}

After data collection, a path analysis model was tested regarding the associated constructs and dimensions (Figure 1).

The SEM specifies the hypothesized model for the 382 teachers. The overall goodness of fit was robust: $\chi^{2}=47.815$; $p=0.284 ; \chi^{2} /$ g.l. $=1.112 ; \mathrm{GFI}=0.978 ; \mathrm{AGFI}=0.966 ; \mathrm{CFI}=0.955$; TLI $=0.943$; RMSEA $=0.017(0.000-0.040)$, confirming that the model represents the relations among the existing variables in our empirical matrix. The Hoelter index values were also adjusted $[\mathrm{CN}=806(0.05)$ and 957 (0.01)].

Table 1 displays the descriptive data corresponding to variables included in SEM. The criteria established are that asymmetry values greater than two and kurtosis higher than seven should not be considered. In this sample, none of the variables approximated these limits, so the estimation of the model fit was carried out.

In answering the general questions presented, from the analysis of Table 2 and the SEM results, it can be seen that the hypotheses were confirmed and all were found to be statistically significant. Thus, women showed higher levels of EI $(\beta=0.15$; $p<0.05)$ compared to men. Teachers with the highest academic training had shown to have higher EI $(\beta=0.14 ; p<0.05)$. Regarding teaching experience, teachers with more experience had shown to have less EI $(\beta=-0.19 ; p<0.01)$.

Considering the relationships between the dimensions of two constructs, it is verified that in situations of conflict management, teachers with higher EI use more integrating strategies $(\beta=0.21, p<0.001)$ and compromising $(\beta=0.14$, $p<0.05)$. However, they used less obliging $(\beta=-0.16, p<0.05)$, dominating $(\beta=-0.13, p<0.05)$, and avoiding $(\beta=-0.12$; 


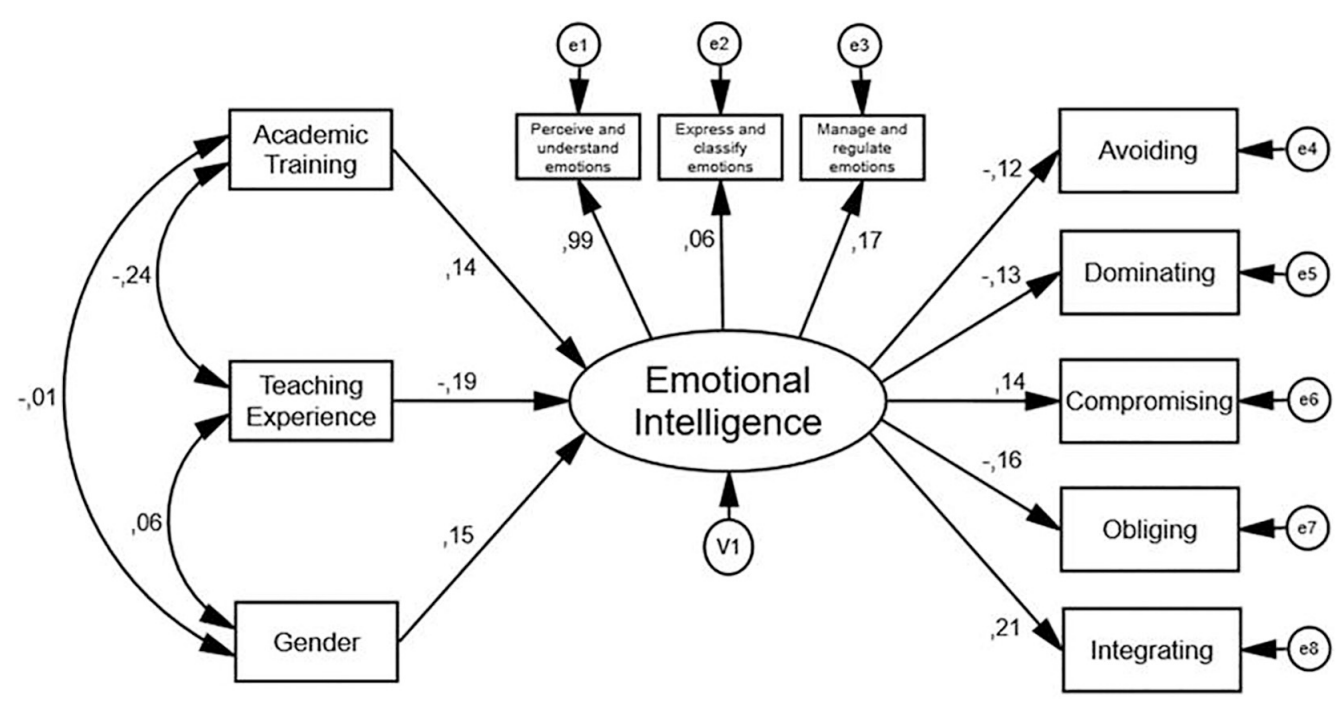

FIGURE 1 | Structural equation model results $(n=382)$.

$p<0.05)$ strategies. All relations are statistically significant, which confirms the hypotheses.

Regarding exogenous variables, it is worth pointing out that the women had more teaching experience $(\beta=0.6 ; p=$ n.s. $)$ and lower levels of academic training $(\beta=-0.01 ; p=$ n.s. $)$. Moreover, a negative and statistically significant relationship appeared between teaching experience and academic training $(\beta=-0.24$, $p<0.001)$, and this relation are statistically significant.

By observing Table 3 concerning Pearson's $r$ correlations among the variables included in the model, although this adjustment with robust values are according to the adjustment values required for each index, the values found are not very expressive; varying the values of these associations were very low $(r<0.200)$ and low $(r \geq 0.200$ and $\leq 0.399)$. It is worth highlighting the more significant association between teaching experience and academic training of teachers $(r=0.237 ; p<0.01)$.

TABLE 1 | Descriptive data for the variables included in the model.

\begin{tabular}{lccrr}
\hline Variable & Mean & Standard Deviation & Asymmetry & Kurtosis \\
\hline Gender & - & - & -0.727 & -1.480 \\
Teaching experience & - & - & -0.320 & -0.687 \\
Academic training & - & - & 0.870 & 1.198 \\
Perceive and & 72.70 & 15.235 & -1.335 & 3.384 \\
understand emotions & & & & \\
Express and classify & 62.83 & 14.769 & -1.524 & 2.941 \\
emotions & & & & \\
Manage and regulate & 68.50 & 9.670 & -0.316 & 2.535 \\
emotions & & & & \\
Integrating & 29.93 & 4.348 & -1.620 & 4.934 \\
Obliging & 21.63 & 5.799 & -0.760 & 0.977 \\
Dominating & 17.19 & 5.201 & -0.513 & -0.171 \\
Avoiding & 20.70 & 6.071 & -0.664 & 0.163 \\
Compromising & 15.40 & 3.514 & -1.423 & 2.737
\end{tabular}

\section{DISCUSSION}

In line with other studies (Gill and Sankulkar, 2017; Valente, 2019), a positive correlation also arose between gender and EI, with the EI being greater in women than in men (hypothesis 1). This finding provides empirical support for a gender difference in EI. In so far as the academic training is concerned, the results indicated that teachers' with more academic training displayed more EI (hypothesis 2) in line with previous studies conducted in Portuguese teachers who also showed that teachers with higher academic qualifications had higher values of EI (Fernandes, 2015; Valente, 2019). Regarding hypothesis 3, which states that a negative and statistically significant relationship is expected between teaching experience and teachers' EI, the results confirm this relationship, probably related with an increase in work stress and burnout, more conflicts in the classroom, and less satisfaction with the profession (Carvalho, 2017), which

TABLE 2 | Results of covariance structure.

\begin{tabular}{lrrcc}
\hline Variable & EVnS & SEV & EE & $\boldsymbol{p}$ \\
\hline Gender $\rightarrow$ El & 0.291 & 0.152 & 0.116 & 0.012 \\
Teaching experience $\rightarrow$ El & -0.187 & -0.186 & 0.067 & 0.006 \\
Academic training $\rightarrow$ El & 0.235 & 0.144 & 0.099 & 0.018 \\
El $\rightarrow$ Integrating & 1.000 & - & - & - \\
EI $\rightarrow$ Obliging & -1.017 & -0.158 & 0.405 & 0.012 \\
EI $\rightarrow$ Dominating & -0.778 & -0.135 & 0.347 & 0.025 \\
El $\rightarrow$ Avoiding & -0.805 & -0.119 & 0.393 & 0.041 \\
El $\rightarrow$ Compromising & 0.528 & 0.135 & 0.235 & 0.024 \\
Covariances & & & & \\
Teaching experience $\leftrightarrow$ Academic training & -0.117 & -0.237 & 0.026 & $*$ ** \\
Teaching experience $\leftrightarrow$ Gender & 0.025 & 0.060 & 0.022 & 0.245 \\
Academic training $\leftrightarrow$ Gender & -0.003 & -0.010 & 0.013 & 0.845
\end{tabular}

EVnS, estimated values - not standardized; SEV, standardized estimated values; EE, estimated errors; $p$, significance level. ${ }^{* * *} p<0.001$. 
TABLE 3 | Pearson's correlation between the variables of the model.

\begin{tabular}{|c|c|c|c|c|c|c|c|c|c|}
\hline Variables & G & TE & AT & El & $\mathbf{I}$ & $\mathbf{0}$ & C & D & A \\
\hline Gender (G) & 1 & & & & & & & & \\
\hline Teaching experience (TE) & 0.060 & 1 & & & & & & & \\
\hline Academic training (AT) & 0.010 & $0.237^{\star \star}$ & 1 & & & & & & \\
\hline Emotional intelligence (El) & 0.085 & $0.134^{\star *}$ & $0.107^{\star}$ & 1 & & & & & \\
\hline Integrating (I) & -0.014 & $-0.131^{*}$ & 0.092 & $0.108^{*}$ & 1 & & & & \\
\hline Obliging (O) & 0.024 & 0.032 & -0.023 & -0.055 & 0.045 & 1 & & & \\
\hline Compromising (C) & -0.024 & 0.010 & -0.003 & 0.089 & 0.028 & -0.034 & 1 & & \\
\hline Dominating (D) & 0.040 & $0.146^{\star \star}$ & -0.073 & -0.042 & 0.059 & 0.068 & -0.065 & 1 & \\
\hline Avoiding (A) & -0.029 & $0.112^{*}$ & -0.028 & -0.045 & -0.008 & 0.091 & -0.060 & $0.147^{* *}$ & 1 \\
\hline
\end{tabular}

${ }^{*} p<0.05 ;{ }^{* *} p<0.01$.

contributes to a decrease in EI. On the other hand, teachers with less teaching experience reveal higher levels of EI, as verified in the research of Sousa (2011) and Valente (2019), with Portuguese teachers.

Considering the relationships between the two constructs, a positive and statistically significant relationship was found between the teachers' EI and integrating strategy (hypothesis 4), like in the study of Aliasgari and Farzadnia (2012). When a teacher uses this strategy, it has, as its main purpose, to find satisfactory solutions for one's own and the student. Thus, in the face of classroom conflict, the teacher proposes alternatives, applies open lines of communication, makes qualification statements, applicants or statements supporting the student, makes concessions, accepts responsibility, maximizes similarities, and minimizes existing differences between self and student. Therefore, the integrating strategy is connected with problem solving in the classroom. The use of this strategy involves openness and exchanging information, being the ideal strategy in dealing with complex classroom problems. Furthermore, the results also support hypothesis 5 about being expected a positive and statistically significant relationship between the teachers' EI and compromising strategy. Previous research carried out in other work contexts supports our results (Shih and Susanto, 2010; Heris and Heris, 2011). By applying this strategy for classroom conflict management, the teacher has intermediate concern for one's own interests and with students' interests, aiming to reach decisions acceptable to both. This is an intermediate strategy on assertiveness and cooperation, which implies a compromise in the search for an acceptable intermediate position for everyone involved in the conflict (Medina and Munduate, 2005). In this strategy, the purpose of the teacher is an intermediate solution for conflict management, do so, it knows how to reduce differences with the student, suggests an exchange of proposals with the student, and provides a quick solution to classroom conflict. Thus, the results indicated that teachers with higher EI use more integrating and compromising, for classroom conflict management. Both strategies are prime to more innovative and useful results, with better satisfaction for the choices taken, among those involved in a conflict, getting more accountable solutions and enhancing the quality of the teaching and learning process.
Results also showed that teachers who tend to have higher levels of EI use less obliging, dominating, and avoiding strategies for classroom conflict management, as studies in other work contexts (Godse and Thingujam, 2010; Villamediana et al., 2015). Thus, based on the hypothesis that teachers with more EI resort less to the obliging strategy (hypothesis 6), the results showed that there is a negative and statistically significant relationship between the teachers' EI and this strategy. The main goal of the teacher when applying this strategy is ceding into student desires. This resorts to behavior complacency, passively agreeing with students' decisions, making concessive statements, and denying or failing to express their own needs, presenting a posture of accommodation and submission in the presence of classroom conflict. Regarding hypothesis 7 , the results showed that there is a negative and statistically significant relationship between teachers' EI and this strategy, confirming hypothesis 7. Using this strategy to manage conflict in the classroom, the purpose is finding a satisfactory agreement for the teacher. Thus, the teacher resorts to the use of his power, with verbal mastery and perseverance; makes statements of confrontation, accusations, criticism, and threats; is sarcastic; asks aggressive questions, and denies responsibility to the detriment of the student involved in the conflict, thus undermining the teaching and learning process. Furthermore, the results also support hypothesis 8, showing a negative and statistically significant relationship between teachers' EI and avoiding strategy. This means that teachers who tend to have more EI make less use of this strategy to manage classroom conflicts. The teacher using this strategy may, in some situations, represent a way of delaying conflict resolution for a subsequent occasion, while in others, it allows the escape of a perceived undesirable situation. When using this strategy, the teacher aims to avoid disagreement with the student. As such, its tactics are abandoning physically and psychologically the conflicts, denying the existence of the conflict, changing or avoiding certain themes, and using uncommitted statements.

The social changes place the teachers before situations that overcome them and for which they were not prepared during their academic training (Extremera et al., 2016), thus it is foreseeable that teachers with low EI apply more strategies related to obliging, dominating, and avoiding. In addition, the teachers who tend to have higher levels of EI apply less these conflict management strategies because they have emotional skills 
that enable them to manage classroom conflicts constructively, using more integrating and compromising strategies. This ratio may be because more emotionally intelligent teachers can adopt a reflexive attitude toward conflict they are confronted with, due to a greater capacity to identify their emotions and adjust them appropriately, as opposed to teachers who have less EI. As some authors indicate, individuals with high EI are more confident, creative, flexible, and better able to cope with their own emotions, with greater problem solving and conflict negotiation skills (Hein, 1996; Maamari and Majdalani, 2019).

Considering the lack of studies that relate how teachers' EI influences the way conflict is managed at a classroom, the strength of the present research is contributing to addressing this gap, with the unique findings of the research question. Thus, the development of teachers' emotional abilities might facilitate the use of constructive strategies for classroom conflict management by using more adaptive emotion regulation strategies for resolving conflicts more effectively. For these reasons, emotional training for teachers will have an important role in classroom conflict and promoting of their constructive management.

Although the results of this research are auspicious, they must be understood in light of some limitations. First, only one research was found that relates teachers' EI to how they manage classroom conflict. Second, all data used in the study were selfreported, may have led participants to respond according to what they consider socially desirable. Third, the sample size limits the generalization of the results. Finally, this study was conducted with a sample of Portuguese teachers, and the results may be different in other countries with different school systems.

Therefore, it would be advisable for future research to use a self-report instrument complemented with qualitative methodology. Portuguese future studies also should be using larger and more diversified samples with a wider range of geographic locations, and future researches based on the results obtained should try to replicate these findings in other countries, with teachers of the same level of education.

\section{CONCLUSION}

Emotionally intelligent teachers represent an important context for the development of positive classroom relationships. Although there are many studies on the benefits of teacher EI in the classroom (Chan, 2006; Brackett et al., 2010; Extremera et al., 2016; Schoeps et al., 2019), there is a shortage of investigations that study how teachers' EI influences classroom conflict management. The results of this research confirmed that teachers with more EI present greater integration and more cohesive levels of commitment for conflict resolution with students in the classroom. They apply more integrating and compromising strategies for conflict management and less

\section{REFERENCES}

Aliasgari, M., and Farzadnia, F. (2012). The relationship between emotional intelligence and conflict management styles among teachers. Interdiscip. J. Contemp. Res. Bus. 4, 555-562. strategy of avoiding, dominating, and obliging. Also, teachers' EI expands the relationship with the students through constructive conflict management, supporting the development of a classroom environment favorable to teaching and learning. Therefore, the present investigation contributed to the knowledge of how teachers' emotional skills related to classroom practice, specifically with conflict management in the teacher-student relationship, helping to overcome the gap between these two constructs, concerning teachers' EI and the strategies used for conflict management.

Based on the research results, practical implications are recommended for the implementation of teachers' emotional education in academic training, in Portugal. Therefore, the development of teachers' EI should be promoted as a resource of excellence for pedagogical practice and be geared toward training and awareness raising in one's EI, during academic training. So, the conflict in the teacher-student relationship does not negatively influence the quality of education. In this context, it is fundamental to assume the teachers' academic training as an aspect of great impact on their professional and personal enrichment, and this should include the development of emotional skills.

Given that the conflict increases in the classrooms of Portuguese schools, the results of this research demonstrated the importance of teachers' EI for constructive conflict management. In conclusion, this research showed that teachers, who have more EI, in the presence of conflict, resort to the use of conflict management strategies that benefit the teaching and learning process, managing conflict in the teacher-student relationship in a constructive way.

\section{DATA AVAILABILITY STATEMENT}

All datasets generated for this study are included in the article/supplementary material.

\section{ETHICS STATEMENT}

The studies involving human participants were reviewed and approved by Directorate General of Education, System of Monitoring of Inquiries in School Environment. The participants provided their written informed consent to participate in this study.

\section{AUTHOR CONTRIBUTIONS}

SV designed the research and drafted the manuscript. AL analyzed data and revised the manuscript. Both authors collected the data. 
Argon, T. (2014). "Conflicts and solutions between students," in Classroom Management, eds T. Argon, and ŞS. Nartgün, (Ankara: Maya Academy).

Brackett, M., Palomera, R., Mojsa-Kaja, J., Reyes, M. R., and Salovey, P. (2010). Emotion-regulation ability, burnout, and job satisfaction among British secondary-school teachers. Psychol. Sch. 47, 406-417. doi: 10.1002/pits.20478

Carvalho, J. S. (2017). Cultivar mindfulness em contexto educacional. Mindmatters 3. Available at: http://mindmattersmagazine.pt/n3-outono2017/cultivar-mindfulness-em-contexto-educacional/

Cejudo, J., and López-Delgado, M. L. (2017). Importancia de la inteligencia emocional en la práctica professor: un estudio con maestros. Psicol. Educ. 23, 29-36. doi: 10.1016/j.pse.2016.11.001

Chan, D. W. (2006). Emotional intelligence and components of burnout among Chinese secondary school teachers in Hong Kong. Teach. Teach. Educ. 22, 1042-1054. doi: 10.1016/j.tate.2006.04.005

Correia, A. A., and Veiga-Branco, A. (2012). "Efeitos da formação em educação emocional nas competências emocionais de professores," in Proceedings of the I Congresso Internacional de Inteligência Emocional e Educação (Oliveira de Azeméis: Escola Básica Comendador Ângelo Azevedo - Projeto CIEE), 1-16.

Extremera, N., and Fernández-Berrocal, P. (2004). La importancia de desarrollar la inteligência emocional en el profesorado. Rev. Iberoam. Educ. 33, 1-9.

Extremera, N. P., Peña, L. R., and Garrido, M. P. (2016). Educadores de corazón: inteligencia emocional como elemento clave en la labor professor. Rev. Padres Maestros 368, 65-72. doi: 10.14422/pym.i368.y2016.011

Fernandes, M. A. L. (2015). As Capacidades da Inteligência Emocional em Professores de Educação Física. Ph.D. thesis, Universidade de Trás-os-Montes e Alto Douro, Vila Real.

Fernández-Berrocal, P., and Extremera, N. (2002). La inteligencia emocional como una habilidad esencial en las escuelas. Rev. Iberoam. Educ. 29, 1-6. doi: 10. 35362/rie2912869

Fernández-Berrocal, P., and Extremera, N. (2005). La inteligencia emocional y la educación de las emociones desde el modelo de mayer y salovey. Rev. Interuniversitaria Formación Profesorado 19, 63-69.

Finney, S., and DiStefano, C. (2013). "Non-normal and categorical data in structural equation models," in A Second Course in Structural Equation Modeling, eds G. Hancock, and R. Mueller, (Charlotte, NC: Information Age Publishing), 439-492.

Gill, G. S., and Sankulkar, S. (2017). An exploration of emotional intelligence in teaching: comparison between practitioners from the United Kingdom \& India. J. Psychol. Clin. Psychiatry 7, 1-6. doi: 10.15406/jpcpy.2017.07.00430

Godse, A. S., and Thingujam, N. S. (2010). Perceived emotional intelligence and conflict resolution styles among information technology professionals: testing the mediating role of personality. Singapore Manag. Rev. 32, 69-83.

Göksoy, S., and Argon, T. (2016). Conflicts at schools and their impact on teachers. J. Educ. Train. Stud. 4, 197-205. doi: 10.11114/jets.v4i4.1388

Goleman, D., Boyatzis, R., and McKee, A. (2002). The emotional reality of teams. J. Organ. Excell. 21, 55-65. doi: 10.1002/npr.10020

Hein, S. (1996). EQ for Everybody: A Practical Guide to Emotional Intelligence. San Francisco, CA: Aristotle Press.

Henderson, L. N. (2006). Emotional Intelligence and Conflict Management Style. Ph.D. thesis, University of North Florida, Jacksonville, FL.

Heris, S. P., and Heris, M. B. (2011). Relationship between emotional intelligence and conflict management strategies in physical education experts of Tehran university. World Appl. Sci. J. 15, 1619-1622.

Hoelter, J. W. (1983). The analysis of covariance structures: goodness-of-fit indices. Sociol. Methods Res. 11, 325-344. doi: 10.1177/004912418301100 3003

Hojbotãa, A. M., Butnaru, S., Rotaru, C., and Tiţa, S. (2014). Facing conflicts and violence in schools - a proposal for a new occupation: the mediation counsellor. Procedia Soc. Behav. Sci. 142, 396-402. doi: 10.1016/j.sbspro.2014.07.698

Hopkins, M. M., and Yonker, R. D. (2015). Managing conflict with emotional intelligence: abilities that make a difference. J. Manag. Dev. 34, 226-244. doi: 10.1108/JMD-04-2013-0051

Jennings, P. A., and Greenberg, M. T. (2009). The prosocial classroom: teacher social and emotional competence in relation to student and classroom outcomes. Rev. Educ. Res. 79, 491-525. doi: 10.3102/0034654308325693

Jordan, P. J., and Troth, A. C. (2004). Managing emotions during team problem solving: emotional intelligence and conflict resolution. Hum. Perform. 17, 195-218. doi: 10.1207/s15327043hup1702_4
Leung, Y. (2010). Conflict Management and Emotional Intelligence. Doctoral dissertation, Southern Cross University, Lismore, NSW.

Lowe, B., Winzar, H., and Ward, S. (2007). Essentials of SPSS for Windows Versions 14, 15: A Business Approach. South Melbourne, VIC: Thomson Learning Australia.

Maamari, B. E., and Majdalani, J. F. (2019). The effect of highly emotionally intelligent teachers on their students' satisfaction. Int. J. Educ. Manag. 33, 179-193. doi: 10.1108/IJEM-11-2017-0338

Mayer, J. D., Caruso, D. R., and Salovey, P. (2016). The ability model of emotional intelligence: principles and updates. Emot. Rev. 8, 290-300. doi: 10.1177/ 1754073916639667

Mayer, J. D., and Salovey, P. (1997). "What is Emotional Intelligence?," in Emotional Development and Emotional Intelligence: Educational Implications, eds P. Salovey, and D. J. Sluyter, (New York, NY: Basic Books), 3-31.

Mayer, J. D., Salovey, P., and Caruso, D. (2002). Mayer-Salovey-Caruso Emotional Intelligence Test (MSCEIT) Item Booklet. Toronto: Multi-Health Systems.

Medina, F. J., and Munduate, L. (2005). "Evaluación de la gestión del conflicto," in Gestión del Conflicto, Negociación y Mediación, eds L. Munduate, and F. J. Medina, (Madrid: Ediciones Pirámide), 73-90.

Meyer, D. K., and Turner, J. C. (2007). "Scaffolding emotions in classroom," in Emotion in Education, eds P. Schutz, and R. Pekrun, (Alpharetta, GA: Elsevier Inc.), 243-258. doi: 10.1016/b978-012372545-5/50015-0

Mora, F. (2013). Neuroeducación: Solo se Pode Aprender Aquello que se ama. Madrid: Alianza Editorial.

Morrinson, J. (2008). The relationship between emotional intelligence competencies and preferred conflict-handling styles. J. Nurs. Manag. 16, 974-983. doi: 10.1111/j.1365-2834.2008.00876.x

Morris-Rothschild, B. K., and Brassard, M. R. (2006). Teachers' conflict management styles: the role of attachment styles and classroom management efficacy. J. Sch. Psychol. 44, 105-121. doi: 10.1016/j.jsp.2006.01.004

Park, H., and Antonioni, D. (2007). Personality, reciprocity, and strength of conflict resolution strategy. J. Res. Pers. 41, 110-125. doi: 10.1016/j.jrp.2006. 03.003

Pérez-de-Guzmán, M. V., Vargas, M., and Amador Munõz, L. V. (2011). Resolución de conflictos en las aulas: un análisis desde la investigación-acción. Pedagog. Soc. Rev. Interuniversitaria 18, 99-114. doi: 10.7179/PSRI_2011.18.08

Pérez-Serrano, G., and Pérez-de-Guzmán, M. V. (2011). Aprender a Convivir. El Conflicto Como Oportunidad de Crecimiento, Vol. 18. Madrid: Narcea, 99-114.

Pestana, M. H., and Gageiro, J. N. (2014). Análise de Dados para Ciências Sociais A Complementaridade do SPSS. Lisboa: Edições Silabo.

Rahim, M. (2002). Toward a theiry oh managging organizational conflict. Int. J. Confl. Manag. 13, 206-235. doi: 10.1108/eb022874

Rahim, M. A. (1983). A measure of styles of handling interpersonal conflict. Acad. Manag. J. 26, 368-376. doi: 10.2307/255985

Rahim, M. A., and Bonoma, T. V. (1979). Managing organizational conflict: a model for diagnosis and intervention. Psychol. Rep. 44, 1323-1344. doi: 10.2466/ pr0.1979.44.3c.1323

Rahim, M. A., and Psenicka, C. (2002). A model of emotional intelligence and conflict management strategies: a study in seven countries. Int. J. Organ. Anal. 10, 302-326. doi: 10.1108/eb028955

Rispens, S., and Demerouti, E. (2016). Conflict at work, negative emotions, and performance: adiary study. Negot. Confl. Manag. Res. 9, 103-111. doi: 10.1111/ ncmr.12069

Schoeps, K., Tamarit, A., Barrera, U., and Barrón, R. G. (2019). Effects of emotional skills training to prevent burnout syndrome in school teachers. Ansiedad Estrés 25, 7-13. doi: 10.1016/j.anyes.2019.01.002

Shahmohammadi, N. (2014). Conflict management among secondary school students. Procedia Soc. Behav. Sci. 159, 630-635. doi: 10.1016/j.sbspro.2014.12. 438

Shih, H., and Susanto, E. (2010). Conflict management styles, emotional intelligence, and job performance in public organizations. Int. J. Confl. Manag. 21, 147-168. doi: 10.1108/10444061011037387

Silva, F., and Dota, L. (2013). "Conflito na escola: um conceito em movimento por meio de narrativas," in Proceedings of the Atas do XII Congresso Internacional Galego-Português de Psicopedagogia (Braga: Universidade do Minho).

Sousa, R. L. V. (2011). Inteligência Emocional dos Professores e Vulnerabilidade ao Stress em Contexto Escolar. Ph.D. thesis, Universidade da Madeira, Funchal. 
Takšić, V. (2001). "Upitnici emocionalne kompetentnosti (inteligencije). [Emotional competence (intelligence) questionnaires]," in Zbirka Psihologijskih Mjernih Instrumenata. [The Collection of Psychological Instruments], eds K. Lacković-Grgin, and Z. Penezić, (Zadar: Faculty of Philosophy in Zadar).

Tarasuik, J. C., Ciorciari, J., and Stough, C. (2009). "Understanding the neurobiology of emotional intelligence: a review," in Assessing Emotional Intelligence: Theory, Research, and Applications, eds C. Stough, D. H. Saklofske, and J. D. A. Parker, (New York, NY: Springer), 307-320. doi: 10.1007/978-0387-88370-0_16

Valente, S. (2019). Influencia de la inteligencia emocional en la gestión del conflicto en la relación profesor-alumno(s). Rev. Estud. Invest. Psicol. Edu. 6, 101-113. doi: 10.17979/reipe.2019.6.2.5786

Valente, S., and Lourenço, A. A. (peer review). Questionário de Inteligência Emocional Do Professor: Adaptação e Validação do "Emotional Skills and Competence Questionnaire". Revista de Estudios e Investigación en Psicología y Educación.
Valente, S., Monteiro, A. P., and Lourenço, A. A. (2017). Adaptação e validação da escala de gestão de conflitos entre professores-alunos. Rev. Estud. Invest. Psicol. Edu. 2, 41-45. doi: 10.17979/reipe.2017.0.02.2512

Villamediana, J., Donado, A., and Zerpa, C. E. (2015). Estilos de manejo de conflictos, inteligencia emocional y desarrollo moral. Rev. Dimensión Empresarial 13, 73-94. doi: 10.15665/rde.v13i1.339

Conflict of Interest: The authors declare that the research was conducted in the absence of any commercial or financial relationships that could be construed as a potential conflict of interest.

Copyright (c) 2020 Valente and Lourenço. This is an open-access article distributed under the terms of the Creative Commons Attribution License (CC BY). The use, distribution or reproduction in other forums is permitted, provided the original author(s) and the copyright owner(s) are credited and that the original publication in this journal is cited, in accordance with accepted academic practice. No use, distribution or reproduction is permitted which does not comply with these terms. 